\title{
The historical development of the corporation and corporate law in China
}

\begin{abstract}
Yuwa Wei*
This article sets out to investigate the development of the corporation and corporate law in the People's Republic of China. It examines the corporate law and practice in this country. The evolution of the corporate system in China happens in the context of its economic reforms, which started in the late 1970s and which is currently in full swing. This grants great significance to the research on this topic. The article attempts to answer the following questions: How are the Chinese going to shape their corporate governance system? Has the corporate governance system been influenced and will it be influenced by any existing corporate governance theories and practice? How has the system of corporate governance developed in the context of the enterprise reform in China? What are the problems existing in China's corporate governance system?
\end{abstract}

\section{Introduction}

As an enormous market, China's economic reforms have attracted great attention from the world. Currently, the economic reforms have come into a crucial stage, a stage of reforming and reconstructing its enterprises. It is a key step towards the final success of the entire economic reforms. The final decision of establishing a modern enterprise system through massive corporatisation was made in 1997. The Fifteenth National Congress of the Communist Party of China clarified that the enterprise reform should be speeded up, and large and medium sized state-owned enterprises should be re-formed into corporations. Since then, the process of corporatisation in China has been accelerated. As more and more enterprises are converted into companies, the issue of corporate governance becomes the focus of the enterprise reform.

Although China's current economic reforms and enterprise reforms are frequently reported in English publications, there is little literature providing a detailed historical review of the development of companies and corporate law jurisprudence. This article attempts to fill this gap. It tries to bring to readers' attention significant literature in Chinese that is developing on the corporations and corporate law. The purpose of this article is to present a clear picture of China's current corporate system. It mainly concerns itself with the following important issues:

(1) How have corporations influenced Chinese society?;

(2) How has the corporate law developed in China?;

(3) How has the system of corporate governance developed in the context of enterprise reform in China?; and

(4) What are the problems existing in China's corporate governance system?

\footnotetext{
* LLB, LLM, PhD, Lecturer in Law, Victoria University of Technology, Australia.
} 
It proceeds with the analyses and discussions in the following order:

Firstly, it discusses the initial development of corporate law and practice before 1949 in China. Secondly, it examines China's enterprise system after 1949 but before the economic reforms in 1978. Thirdly, it introduces the progress of enterprise reform and corporatisation in China. Fourthly, it examines the current situation of corporate law and practice in relation to corporate governance in China.

\section{The initial development of the corporate system}

Traditional China had a totally different experience from Western nations in relation to philosophy, and social and political orientations. Since the Han dynasty (206 BC-24 AC), traditional China followed a policy of 'promoting agriculture and restricting trades'.${ }^{1}$ As a result, although partnerships appeared as early as in the Spring and Autumn Period (770-476 BC) and became highly developed to a degree akin to the Commenda and Societasin the Ming and Qing Dynasties (1368-1911), they never evolved into a business form resembling the modern company. ${ }^{2}$ Hence, the initial development of a corporate system and corporate law was a sheer matter of transplantation from the industrialised world.

The word 'company' (gongsi) first appeared in an official Chinese document in $1687 .{ }^{3}$ When the governor of Fujian province reported to the Qing emperor that he had seized the cargo of the Zheng Chenggong Government, he mentioned that some seized goods were some 'companies' assets' (gongsi huowu). Zheng Chenggong was the General and the Governor of Taiwan at the end of the Ming dynasty. When the Manchus conquered mainland China and replaced the Ming with the Qing dynasty, Zheng declared that his government in Taiwan was a continuation of the Ming dynasty. As a result, Taiwan did not come under the rule of the Qing Government until 1683, after Zheng's death. ${ }^{4}$ Chinese scholars believed that the term gongsi was invented by the Taiwanese while dealing with the Dutch East India Company, and thereafter was widely adopted by various social institutions. ${ }^{5}$ Gongsi was not specially used to refer to the particular business form of the corporation until 1842, when scholar Wei Yuan wrote his book Mastering the Ocean (Hai Guo Tu $\mathrm{Zi}$ ). Following Wei Yuan, many Chinese intellectuals began to discuss corporate concepts and systems. In their works, the importance and contribution of the corporation to modernisation was held in extremely high regard. ${ }^{6}$ Such promotion of the corporate system has had the positive result in drawing society's attention to the corporate system.

Companies began to physically appear in China after the Opium War

1 For example, business was heavily taxed. The law provided severe punishments on breaches in the course of business transactions. Sea trade was forbidden many times.

2 See S J Huang, Companies, People's University Publishing House, Beijing, 1989, p 71.

3 See Y K Zhu, Corporate Governance, Publishing House of Guangdong, China, 1999, p 17.

4 See Y Yong and A Cotterell, Chinese Civilisation from the Ming Revival to Chairman Mao, Book Club Associates, London, 1977, p 75.

5 See Zhu, above n 3. Also see Z Luo, 'Seeking for the Origin of Gongsi', ZHONG HUA GONG SHANG SHI BAO, 1 August 1995.

6 Tao Wang, Fucheng Xue, Guanying Zheng, Chen Chi, and Yan Fu were the initiators of this literature. 
(1840), which was the beginning of the infiltration of Western imperialism into China. China was forced to open up to accommodate Western imperialist expansion. Foreign capitalists began to set up various companies, which began to issue their shares to both foreign and Chinese investors in places such as Shanghai. ${ }^{7}$ They were the earliest companies in China, and they mainly concentrated on sea transportation, shipping, banking, electricity power plants, and textiles. ${ }^{8}$

The Qing Government began to recognise the significance of the corporation to the development of national industry and it was willing to promote and to support corporate activities. ${ }^{9}$ Some officials of the Qing Government initiated a 'foreign affair movement' aimed at modernising China and establishing national industry by learning from the West. The movement resulted in the establishment of the earliest Chinese companies. These companies could be divided into three categories: (1) companies owned and managed by the government; (2) companies owned by merchants but managed by the government; and (3) companies jointly owned and managed by the government and merchants. ${ }^{10}$ In these companies, the government could directly interfere in every matter including the appointment of directors and executives. The government could freely dispose of the assets of the companies. ${ }^{11}$ Other shareholders basically exercised no shareholders' rights apart from their right to dividends (guanli). The rates of guanli were fixed in the articles of association and guanli had to be distributed to shareholders on time, no matter whether the companies made profits or not. Obviously, these companies were not modern companies in a strict sense, although some were faster to imitate the practice of foreign companies, such as issuing shares to the public.

Later, companies established by private capital appeared in China. This was a significant step of corporate development in China. These companies were true commercial companies with no government capital or involvement. The first company promoted by private capital was set up in 1866. More came in the following years. From 1895 to 1911 the numbers of these types of companies began to increase. However, they chiefly concentrated on light industries because of limitations of capital resources, technology and managerial skills. ${ }^{12}$

Lack of experience and a legal framework caused many problems for early corporate activities in China. Equity investment became the hottest business in cities such as Shanghai. Companies' shares were sold at incredible prices.

\footnotetext{
7 See Z G Chen, The Historical Materials of Present Chinese Industries, Vol 4, Sanlian Publishing House, Beijing, 1961, p 57.

8 See Y Y Ji and W Q Fang (Eds), The Economic History of the Society of the Republic of China, China Publishing House of Economy, Beijing, 1991, pp 11-33.

9 See C K Lai, 'The Qing State and Merchant Enterprise: The China Merchants' Company 1872-1902' in R Ampalavanar Brown (Ed), Chinese Business Enterprise, Vol 4, Routledge, London, 1999, p 100.

10 Ibid, p 101

11 For example, in 1885, the Qing Government took away the reserve fund 100,000 taels from Zhaoshangju, a merchant owned and government managed company. In 1896, the government took away another 800,000 taels from the company.

12 See Y P Liu, G L Zhang and C Meng (Eds), Complete Works on the Company Law of the People's Republic of China for Practice, Harbin Publishing House, China, 1994, pp 16-17.
} 
Soon the bubble burst and it resulted in a financial crisis in Shanghai in 1883, which was followed by a number of cases of corporate bankruptcy. Corporate accountability began to attract public attention. ${ }^{13}$

The early development of corporate practice and the desire to promote corporate activities in order to accelerate national industrialisation, motivated the Qing Government to make a law to regulate and protect corporate practice. Qing officials Liu Kunyi and Zhang Zhidong in their famous memorial to the throne stated:

Since trading with foreign countries, large businesses have been dominated by foreign businessmen. Chinese businessmen can only engage in some small business. This is because foreign trade and manufacture require large amounts of capital that cannot be supplied by a few individuals. Foreign companies have the strength because they can pool capital from hundreds and thousands investors. America and some European countries have the most detailed and explicit corporate legislation and their governments are keen to support their corporate activities. This leads to the prosperity of their economies. China has conventionally underestimated commerce and neglected commercial legislation. As a result, merchants gain self-interest through deception. The shrewd profit by fraudulence and the unskilled receive all the detriments. This is the reason that the Chinese regard investment as a difficult matter and dare not compete with foreign traders. Once disputes between Chinese traders and foreign traders arise, foreign consuls usually shield foreign traders. As a result, Chinese merchants either invest in foreign companies, or set up fake foreign companies and employ rascals to be protectors. If the government does not deal with the matter immediately, Chinese merchants will never be able to compete with foreign merchants. China must have commercial law. Then, Chinese businessmen can rely on the law and have no worries. They can establish transport companies and manufacturing factories of high productivity. ${ }^{14}$

This view was reiterated in an imperial edict instructing the drafting of Chinese commercial law. Emperor Guang Xu stated in the imperial edict:

Trade and industry are important national affairs. The tradition of regarding industry and commerce as inferior occupations has been carried on for so long. This is the main cause for the decline of our national economy and the destitution of the people's livelihood. There is the necessity to change the situation and give special attention to industry and commerce. ${ }^{15}$

In 1904, the Qing Government enacted the first Chinese company law, Gongsilu. The law had 11 divisions and 131 articles. It was based on the 1855 Companies Act (UK), the 1862 Companies Act (UK), and the 1899 Commercial Code (Japan). ${ }^{16}$ It was therefore a hybrid of common law and civil law. ${ }^{17}$ Since the enactment of the 1904 Company Law (gongsilu), the term 'gongsi' has formally been used to refer to the corporation. The law contained fundamental principles of corporate practice. It had provisions about corporate registration procedure, shareholders' rights and meetings,

13 See J M Dou, Research on the History of Corporate Ibideology in China, Publishing House of Shanghai University of Finance and Economics, Shanghai, 1999, p 18.

14 See L M Li, The Comparison of Chinese and Japanese Enterprise Systems, Law Publishing House, Beijing, 1998, pp 74-5.

15 Ibid, p 75.

16 The Japanese 1899 Commercial Code was based on German corporate legislation.

17 See B S Wang and Q Z Cui, The Theory of the Chinese Company Law, Literature of Social Science Publishing House, Beijing, 1998, p 8. 
directors' duties and board meetings, amendment of constitutions, accounts, dissolution, and penalties. The law provided for four types of company, hezi gongsi (partnership), hezi youxian gongsi (limited partnership), gufen gongsi (joint stock company with limited and unlimited shareholders), gufen youxian gongsi (company limited by shares). ${ }^{18}$ The main contribution of the law was the introduction of the last type of company, gufen youxian gongsi, which was really a modern company. Companies were required to have at least two or seven members with no top ceiling. Separate personality was recognised for the first time. All companies had to be registered with the Ministry of Commerce in Beijing. ${ }^{19}$

The enactment of the law further encouraged industrial activities. Up until the end of the Qing dynasty in 1911, there were 615 factories. ${ }^{20}$ Among them, 521 factories were set up by Chinese entrepreneurs. ${ }^{21}$ Nevertheless, it was assessed that the law was not as adequate and successful as expected in terms of encouraging corporate operations. ${ }^{22}$ This may have been due to the fact that the law's vague and ambiguous provisions that were 'badly translated from two other nations' experience engendered distrust'. ${ }^{23}$ By 1908 only 21 of 227 registered companies were significant in size. ${ }^{24}$ Consequently, the Qing Government saw a need to amend the existing Company Law. The amendment work began in 1908. A revised version of the Company Law was finalised but never enacted, as the Qing Government collapsed and China became a republic in 1911.

The early republican government maintained the 1904 Company Law until 1914. In 1914, the government enacted the Company Regulations. The new law was based on the unpublished revision of the 1904 Company Law. The 1914 Company Regulations adopted the German model of corporate legislation and it was a clearer corporate code compared to the 1904 Company Law. The new code provided for four types of company including wuxian gongsi (unlimited company), lianghe gongsi (joint company), ${ }^{25}$ gufen lianghe gongsi (joint share company), ${ }^{26}$ and gufen youxian gongsi (company limited by shares). It provided that banks should be formed as companies limited by shares (gufen youxian gongsi). The new law had a considerable effect on the promotion of corporate activities. The period from 1914 to 1927 was a time during which commercial activities developed rapidly in China. In 1920, the

18 Company Law (1904), Art 1. Although these firms were called companies (gongsi), some of them were not modern companies but partnerships.

19 Ibid, Art 2.

20 See Liu, Zhang and Meng, above n 12, p 15.

21 Ibid.

22 See W C Kirby, 'China Unincorporated: Company Law and Business Enterprise in Twentieth-Century China' (1995) 54 The Jnl of Asian Studies 43-63.

23 Ibid.

24 Ibid.

25 A joint company had at least one limited liability shareholder and one unlimited liability shareholder. The later would manage the company, whereas the former only provided capital.

26 The difference between a joint share company and a joint company was that a joint share company issued shares to the general public. 
number of factories reached $1759 .{ }^{27}$ From 1911 to 1920 there were 807 registered companies. ${ }^{28}$

The most distinctive characteristic of Chinese corporate practice during the initial stage of corporate development was the experiment of establishing companies with merchant investment but State management. This type of business form was a product of the special social and economic situation of China at that time. Experience showed that when foreign corporations became dominant in many of a country's trades, government support and subsidies were important to the development of national corporations. ${ }^{29}$ In China's early state of corporate development, Chinese entrepreneurs sought the government's support and protection. They were willing to establish a relationship of mutual dependence with the government. This was a matter which the government had also been considering. From the mid-19th century, the Qing Government was under consistent pressure to increase its military spending. ${ }^{30}$ This resulted in the available funds being heavily allocated to national defence. ${ }^{31}$ Consequently, the government's capacity to develop civil industries suffered. There were trades over which the government saw a necessity to retain central control, for example, water transportation. A solution was to pool necessary funds from rich individuals. As a result, companies, in which merchants invested but the government controlled, came into being at that time. From the publications of the time, we can perceive that this type of company was not only preferred by the government and merchants, but also favoured by academics. ${ }^{32}$

Later, however, the manner of governance in this type of company was criticised. People began to see the unattractiveness of administrative interference in corporate management. There were calls for separation of the State and enterprises. The 1904 Company Law put the issue to an end by omitting this type of company and by stressing the equal rights of all shareholders. After that, companies invested in by merchants and managed by the government were gradually nationalised or privatised.

\section{The corporate system during the nationalist period}

In 1927, the Nationalist Party took over the government of China. Once in power, it initiated a movement of bringing economic development under state control. It endeavoured to retain government control over a number of companies in important sectors. The movement was influenced by a belief that the expansion of private capital should be checked by the State. Around the beginning of the nineteenth century, people became increasingly aware of the negative impact of corporate development. Many believed that the development of private enterprises would exacerbate economic monopoly and social division. ${ }^{33}$ It was therefore necessary to develop pubic enterprises and

\footnotetext{
27 See Liu, Zhang and Meng, above n 12, p 17.

28 Ibid.

29 For example, the corporate development in Japan fell in the case.

30 See Lai, above n 9, p 107.

31 Ibid.

32 See Dou, above n 13, pp 24-5.
}

33 Ibid. 
to enhance the utilisation of State capital in the national economy. The founding father of the Nationalist Party and the Nationalist Government, Sun Zhongshan, pointed out that the industries concerning the people's livelihood and the national economy were not to be controlled by private capital. ${ }^{34}$ The discussion focused on how to establish public enterprises. Many favoured the forms of state-owned companies where the State was the sole shareholder, State holding companies in which the State controlled parent companies, and joint companies in which the State and private individuals jointly invested. ${ }^{35}$

As a result, government enterprises expanded rapidly and soon gained a dominant position in the national economy. After the Second World War, the Nationalist Government confiscated the assets of all former Japanese companies and State capital further swelled. At this point in time, the government possessed an amount of capital between US\$100-200 billion. ${ }^{36}$ The government controlled $80 \%$ of total industrial capital and monopolised the banking system. ${ }^{37}$ The initial effort to avoid a private monopoly resulted in a State monopoly. Then, the State monopoly turned into a bureaucratic monopoly under a corrupt government, as State enterprises were used to pursue individual interests of government officials. ${ }^{38}$ The Chinese knew that State enterprises and capital were basically controlled by four families. ${ }^{39}$ Thus, corporate development during the Nationalist ruling period was described by the Chinese as bureaucratic monopoly capitalism, referring to the change from State capitalism to bureaucratic capitalism.

Surviving under the domination of foreign capital and bureaucratic capital, privately-owned companies were usually small in size and capital. Their economic efficiency and productivity were low, and their technology, equipment, and management were backward. They relied heavily on foreign capital and technology. ${ }^{40}$ All of these elements limited and shaped the development of privately-owned companies. They were concentrated in a few light industry sectors such as silk reeling and textiles, which heavily relied on foreign markets. ${ }^{41}$ Most of them were located in a few coastal cities for the convenience of importing technology and equipment and of shipping their products abroad. ${ }^{42}$

The rampage of bureaucratic capitalism attracted a tide of criticisms as people saw the evils caused by it: it suffocated the development of the private sector; it became an instrument used by a group of individuals to enrich

\footnotetext{
34 See Z S Sun, 'The Speech at the Farewell Party for the Members of Tongmeng Society' in Complete Works of Shun Zhongshen, Vol 2, Zhonghua Publishing House, Beijing, 1982, p 322 .

35 Ibid. Also see Dou, above n 13, pp 64-6.

36 See Liu, Zhang and Meng, above n 12, p 16.

37 Ibid.

38 Ibid.

39 This refers to Jiang, Song, Kong, and Chen four families. All had connections in the government. Jiang was the family of president Jiang Jieshi; Song was the family of the president's wife; Kong was family of the brother in law of the president; and Chen was the family of two high rank officials with some special relationship with the president himself and his family members.

40 See Liu, Zhang and Meng, above n 12, pp 16-17.

41 Ibid, p 17.

42 Ibid.
} 
themselves; it brought administrative interference to corporate management; it devastated the national economy; and it was responsible for disastrous inflation in the late $1940 \mathrm{~s} .{ }^{43}$ Calls to promote the private sector and to separate the government from enterprise management arose. ${ }^{44}$

Despite the disastrous practice of State capitalism, company legislation was further developed under the Nationalist Government. In 1929, a new Company Law with 233 Articles was promulgated and ultimately became effective two years later (July 1931). The law reflected the government's intention to regulate corporate activities closely. Companies limited by shares were regulated further and more penal provisions with heavier punishments were imposed for conduct in breach of the legislation. Some held that the 1929 Company Law was too strict. As a result, it bridled the spirit of business people..$^{45}$

Two central objects of the 1929 Company Law were to give more protection to small shareholders and to limit the rights of large shareholders. For example, it stated that, in a company limited by shares, a shareholder's voting rights could not exceed one-fifth of the votes of all shares regardless of what their actual shareholding was. ${ }^{46}$ However, this did not apply to a company in which the government had shareholdings.

With the end of the Second World War, the Nationalist Government amended the 1929 Company Law and enacted the New Company Law in 1946. The amendment attempted to regulate company conduct in postwar circumstances. An important change was the end of foreign extraterritoriality, ie, Chinese company law began to apply to foreign companies within China's territory. The 1946 New Company Law introduced another two types of companies, youxian gongsi (limited company) and waiguo gongsi (foreign company). Members of a limited company were restricted to 10 at most. The purpose of providing the new categories of company was to entrench the government's control in those newly confiscated Japanese companies. ${ }^{47}$ The 1946 New Company Law was soon annulled in mainland China as a result of the Communist victory. In 1949, the Communist Government announced the establishment of the People's Republic of China. Afterwards, China switched to a planned economy until the late 1970s.

In summary, from the mid-19th century, the corporation and corporate law in China gradually developed. The Chinese Government and its people placed great hope in the ability of the corporate system to accelerate the process of China's modernisation. As a result, the government endeavoured to build a strong corporate system that was closely under the State's control. However, the early practice of establishing companies that were owned by merchants but

43 See Y N Wang, 'The Theoretical Analyses on the Bureaucratic Capitalism of Chinese' in The Chinese Economy, Living Publishing House, China, 1947, pp 252-4; Generally see D X Xu, The Way Out for the Chinese Entrepreneurs, Publishing House of New Democracy, China, 1949. See also D X Xu, Bureaucratic Capitalism, Ocean Publishing House, China, 1952, p 55; and Y C Ma, Ma Yingchu Criticises Bureaucratic Capitalism, Publishing House of Chongqing, China, 1983, pp 149, 153 and 185.

44 Ibid.

45 See Z Y Zhang, New Company Law Annotated, Lixin Publishing House, Shanghai, 1946, p 1 . See also Kirby, above n 22, at 43 and 52.

46 Company Law (1929) Art 129.

47 See Kirby, above n 22, at 43 and 54. 
supervised by the government and later efforts to promote State capitalism, all contradicted the basic policy. The enterprises under State intervention did not prosper, and the whole economy suffered the consequences.

The theory of developing the public sector was not unsound and the government's support and guidance for corporate development had proved necessary in some other industrialised countries such as Germany and Japan. In China, the theory's practical implementation went wrong. The biggest lesson for the Chinese was that government support and guidance should not be exercised by direct administrative intervention in corporate governance. Instead of directly managing the day to day business of state-owned companies, the government should have designed a workable system that enabled the government to control the companies effectively by using suitable agents who could realise the State's ownership rights in these companies more efficiently.

\section{Corporate development from 1949 to 1978}

\section{(i) The recovery of the national economy}

After the civil war, the new Communist Government concentrated on the recovery of China's national economy. The new government was determined to build a socialist economic system in China as envisaged by Marx. This system was supposed to be a centrally planned economic system, where economic activities would follow administrative plans of the State rather than market and price systems.

The economic policy of that period was formed according to Mao's thoughts on a new democratic economy. ${ }^{48}$ The essence of the policy was to eliminate bureaucratic capitalism ${ }^{49}$ in China. The private sector was protected because it was not dominant and it could contribute to the country's economy. Hence, the government's principal policy of enterprise development at the time was to confiscate bureaucratic enterprises and to protect private enterprises. The first step taken by the government was for the State to confiscate bureaucratic enterprises. The next step was to transform private enterprises into joint state-private enterprises and then convert them into state-owned or collectively-owned enterprises.

Within the new democratic economy, economic structure was divided into different components according to ownership. Thus, there was a State economy, ${ }^{50}$ a semi-State economy, a mixed economy, a capitalist economy, ${ }^{51}$

48 Generally see Z D Mao, 'The Chinese Revolution and the Chinese Communist Party' in M Zedong, Selected Works of Mao Zedong, Foreign Languages Press, Beijing, 1965, pp 305-34. Also see Z D Mao, 'On Coalition Government' in Z D Mao, Selected Works of Mao Zedong, Foreign Languages Press, Beijing, 1965, pp 205-70.

49 The Chinese use this term to describe the nature of capitalism in the Nationalist era in which bureaucrats controlled State companies, which predominated the national economy, to pursue their personal interests.

50 State economy referred to the proportion of the national economy that was under the PRC State control.

51 Capitalist economy referred to the proportion of the national economy that was under the control of Chinese capitalists. Basically, capitalist economy comprised the private sector under nationalist government. 
an individual economy, ${ }^{52}$ and a State capitalist economy. ${ }^{53}$ These economic components co-existed during the economic recovery period. Accordingly, enterprises were classified as state-owned enterprises, collective enterprises, private enterprises, individual enterprises and mixed enterprises. The traditional categories of enterprises including companies, partnerships and sole traders were largely ignored. The new enterprise categories gave a clearer indication of which enterprises were subject to ongoing socialist reform.

In order to regulate private enterprises, which were still large in number, the government enacted the Interim Regulations Concerning Private Enterprises in 1950. In the following year, the Implementing Methods of the Interim Regulations Concerning Private Enterprises came into effect. In both pieces of legislation, private enterprises were divided into sole traders, partnerships and companies. The legislation provided for five types of companies: wuxian gongsi (unlimited companies that have at least two unlimited liability shareholders); youxian gongsi (limited companies that have at least two limited liability shareholders); lianghe gongsi (joint companies that have at least one unlimited and one limited liability shareholder); gufen youxian gongsi (companies limited by shares that must have at least five shareholders) and gufen lianghe gongsi (joint share companies that have at least one unlimited liability shareholder and five limited liability shareholders). ${ }^{54}$ In these companies, shareholders exercised their residual rights via shareholders' meetings. ${ }^{55}$ In a company limited by shares, the executive power was exercised by the board of directors; 56 in a limited company, by the executive shareholders or directors; ${ }^{57}$ and in a joint company or a joint share company, by the executive shareholders with unlimited liability. ${ }^{58}$

An important characteristic of the 1950 legislation was that it introduced a provision that enabled the State to incorporate productive activities of private enterprises into its economic plan. Article 6 stated:

for the purpose of overcoming economic anarchy, adjusting the relationship between production and marketing, and developing toward a planned economy, if necessary, the government may make production and marketing plans in relation to certain important products, which should be complied by both state-owned and private enterprises. ${ }^{59}$

This provision paved the way for further reform of private enterprises into state-owned or collective-owned enterprises.

In short, during the economic recovery period, the country's policy toward private enterprises could be summarised in a few words: use, restrict, and

52 Individual economy referred to the proportion of the national economy that was under the control of sole traders. These people managed some small businesses such as retailing shops. These businesses and capitalist economy could be classified as the private sector. They were singled out because they were under a separate reform scheme.

53 Later, the policy was embodied in the Constitution of the People's Republic of China, 1954. State and capitalist economy refers to the cooperation between the State economy and capitalist economy.

54 Interim Regulations Concerning Private Enterprises (1950), Art 3.

55 Ibid.

56 Ibid, Art 19.

57 Ibid, Art 20.

58 Ibid, Arts 21 and 22

59 Ibid, Art 6. 
reform. While encouraging private enterprises to make economic contributions to the country, the government took steps to prepare for their peaceful reformation into state-owned and collectively-owned enterprises.

\section{(ii) Reforming private enterprises and developing state-owned enterprises}

In 1953, the government launched its first five-year economic plan, and the process of reforming private enterprises accelerated. The government proposed a general policy of 'one realisation and three reforms', ie, realising industrialisation and reforming the agricultural sector, the small business sector, and the private sector. In relation to private enterprises, reform methods included ordering goods, unified purchase and sale by the State, and restructuring the enterprises to become joint state-private enterprises (mixed enterprises).

With an increasing number of private enterprises being transformed into joint state-private enterprises, the 1950 Interim Regulations for Private Enterprises had a decreasing number of entities to regulate. The types of companies defined in the legislation gradually became extinct, except for the limited company, which was still used by joint state-private enterprises. In 1954, the country enacted the Interim Regulations for Joint State-Private Enterprises. The regulations provided guidance for the organisation of joint state-private enterprises. Joint state-private enterprises usually took the form of limited companies. Their shareholders were the State and private investors. All shareholders had limited liability to the value of their shares. ${ }^{60}$ The State would appoint representatives to participate in management. If they were large in size and in shareholders, such enterprises had boards of directors to discuss and decide business affairs. There were no general meetings, but there were private shareholders' meetings which only dealt with internal matters between private shareholders. ${ }^{61}$ Such an organisational arrangement ensured that power was concentrated in the boards. The State could enhance its control over the enterprises by controlling their boards, and it eventually dominated them.

Before the enactment of the 1954 Interim Regulations for Joint State-Private Enterprises, the State and the private shareholders of a joint state-private company appointed directors respectively. The number of directors was distributed to each side according to their share proportions. The 1954 regulations discarded this practice. Article 20 of the regulations stated that the number of directors appointed by each side should be decided through negotiation. The regulations further clarified that 'joint state-private enterprises are subject to the leadership of the State, and are jointly managed by State representatives and private agents'. They also provided that the issues should be submitted to the authoritative department for resolution if shareholders could not reach agreement on important matters. ${ }^{62}$ It was evident that the regulations further departed from traditional corporate practice and

\footnotetext{
60 Ibid, Art 8.

61 Ibid, Art 22.

62 Ibid.
} 
brought joint state-private enterprises' activities closer to those of state-owned enterprises.

By 1956, all private enterprises were converted into joint state-private enterprises. In 1956, the State Council ${ }^{63}$ enacted new rules that fixed the dividends of private shareholdings in joint state-private enterprises at $5 \%$ per year. ${ }^{64}$ The rules also required dividends to be paid for a period of seven years (later changed to 10 years) regardless of whether the enterprise made profits or not. ${ }^{65}$ The new rules, in fact, converted private shareholders into creditors. As a result, the majority of joint state-private enterprises, the only remaining limited companies, were converted into state-owned enterprises, and the rest were transformed into collectively-owned enterprises. state-owned enterprises were those in which the State claimed absolute ownership as well as managerial rights. ${ }^{66}$ Collective enterprises were those in which local governments had ownership and managerial rights. ${ }^{67}$ Regarding state-owned enterprises, China adopted a method of 'uniform ownership, but hierarchical control'. Thus, there were such state-owned enterprises that were owned by the central government but controlled by local governments. ${ }^{68}$

After three years' economic recovery and five years' economic reform, China basically converted all the private enterprises into state-owned or collective-owned enterprises. As a result, traditional companies became extinct after 1956. After that, China had an enterprise system of public ownership and all enterprise activities were under the administrative control of the State. Although some enterprises still kept the word 'company' in their names, they were not traditional companies anymore. Firstly, they carried on their businesses for the purpose of implementing economic plans, not making profits. Secondly, they operated according to the requirements of administrative plans, not the demand of the market. And thirdly, their internal organisational structure differed from that of a company. This situation lasted for about 23 years until the initiation of the economic reforms in 1978.

During the period of economic recovery and transition into a socialist economy, the state-owned enterprise system appeared to be successful. ${ }^{69}$ The country's economy performed impressively. Later, however, economic development slowed down and eventually faltered after $1958 .^{70}$ The uniform public ownership and the total absence of market competition began to impact

63 The central government of the PRC.

64 The two pieces of legislation were: the Provisions regarding the Promotion of Fixed Dividends in Joint State-Private Enterprises and the Instructions on Some Questions about Reforming Private Industrial and Commercial Sector, Private Handicraft Sector, and Private Transportation Sector.

65 See Wang and Cui, above n 17, p 15.

66 See Z P Gan, The Law of Enterprises and Companies, Beijing University Publishing House, Beijing 1998, p 102.

67 Ibid, p 152.

68 See X H Chen, 'Chinese and Japanese Enterprise System: Some Descriptions and Analyses' in $\mathrm{L} \mathrm{M} \mathrm{Li} \mathrm{(Ed),} \mathrm{The} \mathrm{Comparison} \mathrm{of} \mathrm{Chinese} \mathrm{and} \mathrm{Japanese} \mathrm{Enterprise} \mathrm{Systems,} \mathrm{Law}$ Publishing House, Beijing, 1998, p 123. See also X H Chen, 'Establishing a New Managerial System for National Capital' in J L Wu (Ed), The Strategic Reforms of State Economy, China Development Publishing House, Beijing, 1977, pp 122-57.

69 See W J Baumol and A Blinder, Economics, Principles and Policy, 4th ed, Harcourt Brace Jovanovich Inc, San Diego, 1988, p 906.

70 Ibid. 
negatively on the economy. There was increasing awareness of the inefficiency of state-owned enterprises. ${ }^{71}$ Quite a few attempts to reform state-owned enterprises were made, but all were in vain. The first reform occurred in 1958. The State decided to transfer $87 \%$ of its enterprises to local provinces and municipalities. However, this was simply a process of changing central administrative control into local administrative control. The reform did little to improve enterprise efficiency. And consequently, the State resumed central control in 1961. The second reform was carried out in 1964. The central government delegated the power to allocate funds and materials for non-industrial projects to local governments. The power was returned to the central government again when the reform proved to be a failure. In 1970, another reform was launched. Half of the state-owned enterprises were turned over to local governments again. ${ }^{72}$ The third reform did not have a better fate than the first two reforms.

The government also experimented with increasing the economic efficiency of state-owned enterprises by establishing enterprise groups. Around the 1960s, China trialled a form of trust (tuolasi). A tuolasi was a union of many enterprises that manufactured similar products or were supplementary to each other in processing and re-processing productive materials. ${ }^{73}$ In a tuolasi, individual enterprises became shareholders and lost their commercial independence. Each enterprise held a certain amount of shares and would receive dividends and bonuses accordingly. A tuolasi was run by its board of directors. ${ }^{74}$ The aim of adopting the tuolasi system was to coordinate specialised enterprises and to achieve managerial efficiency. The trial of tuolasi brought some visible improvement in productive efficiency. ${ }^{75}$ However, it was not as successful as expected. It did not mitigate the problem of administrative intervention that is inherent in a planned economy. ${ }^{76}$ Before further reform measures were put into practice, the Cultural Revolution 77 began, which not only brought political turbulence but also caused a recession of economic development in China. The method of tuolasi was soon to be rejected.

In summary, the new government made great efforts to end bureaucratic capitalism in China. It confiscated all bureaucratic capitalist enterprises. However, unlike the governments in the Soviet Union and some other socialist countries, the socialist government in China did not nationalise private enterprises immediately. It took a more gradual and peaceful approach to reform them into state-owned and collectively-owned enterprises. This strategy proved to be successful. In fact, all government policies concerning

71 Ibid.

72 See State Economic Committee, Report on the Discussions about Making a Trial of Industry and Transportation Trust, 1964.

73 Ibid

74 Ibid.

75 See Liu, Zhang and Meng, above n 12, p 17.

76 Ibid.

77 Cultural Revolution was a movement initiated by Chairman Mao Zedong in 1966. It was started for the purpose of eliminating the perceived political elements that endangered the stability of the Communist Government. The movement lasted for approximately 10 years and resulted in economic recession. See Y W Wei, Investing in China: The Law and Practice of Joint Ventures, The Federation Press, Sydney, 2000, p 27. 
enterprise reforms at that time were carried out effectively. However, the government later found out that the economic performance of state-owned enterprises was not as satisfactory as anticipated. Efforts were made to improve the performance of these enterprises, but they were wrongly focused. The strategies did not aim to reduce administrative intervention and to increase market mechanisms, but to transfer control to different administrative authorities. The expectations of the reforms could not therefore be met. The Chinese experience from 1949 to 1978 illustrates that a total withdrawal of market mechanisms and modern corporate governance from an enterprise system cannot increase economic efficiency of enterprises within it. The Chinese paid the price for this historical lesson. Thus, since the commencement of the economic reforms in 1978, China has determined to build a market economy and a modern enterprise system.

\section{The enterprise reforms after 1978}

Since 1978, China has carried out its economic reforms aggressively. The goal of the economic reforms is to industrialise the country by building a market economy. In contrast to other former Eastern bloc countries, the Chinese have adopted a gradual reform strategy that has combined the introduction of market forces, gradual reduction of mandatory planning, decentralization and autonomy in economic management and opening the economy to international trade and foreign investment' ${ }^{78}$ After two decades, the economic reforms have produced rapid economic growth and broadly shared income gains in Chinese society. However, upon closer examination, one can perceive that China's stunning economic performance after the economic reforms has been largely attributable to the liberalisation of the agricultural sector and the rapid growth of non-State industry, including township and village enterprises. ${ }^{79}$ The fundamental reforms of state-owned enterprises were much postponed until the end of the 1990s. Before that, less radical reform measures were implemented in state-owned enterprises with limited success. Since 1997 the government has accelerated the enterprise reform, after seeing the costs of its postponement. According to the reform agenda, state-owned enterprises are to be reformed into modern companies, and some of them are to be privatised. The Chinese regard the far-reaching enterprise reform as a decisive step towards the ultimate success of the economic reforms.

\section{(i) Corporatisation in the enterprise reform}

During nationalisation in the 1950s, traditional companies were replaced by state-owned and collectively-owned enterprises. Since the economic reforms, the country has promoted a number of specialised companies and groups of companies. ${ }^{80}$ In 1978, some specialised companies, groups of companies and

78 See H G Broadman, Meeting the Challenge of Chinese Enterprise Reform, The World Bank, Washington DC, 1995, p 2.

79 See N R Lardy, China's Unfinished Economic Revolution, Brookings Institution Press, Washington DC, 1998, p 3.

80 See Central Committee of the Communist Party of China, Decisions on Increasing Industrial Development, draft, 1978; State Council, Provisional Regulations Concerning Promoting Economic Alliances, 1980; State Council, Regulations Concerning Problems of 
headquarters were firstly established in Beijing, Shanghai, Tianjing and Shenyang. After 1979, the laws concerning Chinese-foreign joint ventures and wholly foreign owned enterprises were enacted, and joint venture enterprises and foreign subsidiaries began to appear in China. These occurrences signalled the recovery of Chinese corporate practice. In 1980, the State Council launched the Interim Regulations for Promoting Economic Cooperation which aimed to encourage the enterprise reform further. More companies were set up. But many companies in existence at this time were actually administrative companies, as labelled by the Chinese. Some of them had existed since the 1950s and 1960s, while some of them were newly formed. Such companies were in fact administrative organisations set up by administrative authorities to control and administrate other enterprises. ${ }^{81}$

The evaluation of the defects of administrative companies started in 1979. Awareness of the economic irrationality of administrative enterprises and companies increased. Discussions found that administrative organisations had replaced economic organisations in the enterprise system, which contradicted economic rationality. Administrative companies were vulnerable to administrative intervention. The economic reforms should have restructured these enterprises into independent economic organisations. ${ }^{82}$ However, there was lack of vision about how to reform the enterprise system in the early discussions.

The idea of reforming the state-owned enterprise system by corporatisation emerged in 1983. The enterprise reform initially stimulated academic discussions that evaluated reform outcome and reform strategies. Some analyses indicated that inefficient allocation of capital and resources was the key problem of China's enterprise system. None of the strategies used in the ongoing enterprise reform effectively tackled these issues. ${ }^{83}$ Managerial autonomy had resulted in waste and depletion of State assets and resources. ${ }^{84}$ The strategy of replacing state-allocated funds with bank loans could not solve the problem of inefficient allocation of capital and resources (the limited direction of capital and resources to highly productive sectors and enterprises). ${ }^{85}$ Moreover, as managers of state-owned enterprises were appointed by administrative departments, the irrational and short-term behaviour of the enterprises persisted. These fundamental problems could only be attacked effectively by building a modern enterprise system through corporatisation. ${ }^{86}$ Notably, the World Bank also recommended that China

Further Promoting Economic Alliances, 1986; State Administrative Bureau of Industry and Commerce, Administrative Procedure of Registering Economic Alliances, 1986.

81 See Liu, Zhang and Meng, above n 12, p 18.

82 See F R Dong, 'The Issues about the Form of Socialist Ownership in Our Country' (1979) 1 Jing Ji Yan Jiu 21 at 25-6. See also J Z He, 'Problems in the Management of a Planned Economy under the System of Ownership by the Whole People and the Orientation of Reforms' (1979) 5 Jing Ji Yan Jiu 35 at 42-5.

83 Generally see J X Wu and L Z Jing, 'Corporatisation: A thought about Further Reform' (1985) 12 Jing Ji Fa Zhan He Ti Zhi Gai Ge1-12. The article was written and internally circulated in 1983, but published in 1985 .

84 Ibid.

85 Ibid.

86 Ibid. 
should reform its enterprise system through corporatisation in a report in 1983.87

The suggestion to reform the enterprise system through corporatisation immediately attracted wide attention in China. In the next few years, intensive debates about corporatisation appeared in many newspapers and periodicals. A large proportion of discussions during this period concerned ideological issues. In the mid-1980s, some cities began the trial of establishing share companies. The government expressed its approval of corporatisation in some official documents in 1986. ${ }^{88}$ In 1987, the Thirteenth National Congress of the Communist Party of China confirmed that the trial of corporatisation should continue.

Early in the corporate experiment many problems emerged, because corporate legislation was not complete and corporate practice was not mature. There were too many companies and some of them did not satisfy basic standards. For example, there were some 'briefcase' companies, with no capital, no site, no stable employees and no equipment. Some companies were set up to make illegal profits. There were also managerial problems in many companies. Up until 1985, there were 300,000 different types of companies in China. ${ }^{89}$ Seeing these problems, the State Council decided to restructure the existing companies and to enhance the regulation of company activities. Furthermore, the State Administrative Bureau of Industry and Commerce enacted the Interim Regulations for Administrating and Registering Companies. After a great deal of effort, the number of companies was reduced to 180,000 . However, the number increased again to 360,000 in $1987 .{ }^{90}$ The State Council called for another restructuring of the existing companies in 1989. Some ill-qualified and managed companies were closed down. By 1990, the number of companies was reduced to $250,000 .{ }^{91}$

With the progress of the economic reforms, corporate activities further developed in the early 1990s. The number of share companies increased rapidly, and many companies issued shares to the general public. Consequently, there was a need to develop a securities market. In 1990 and 1991, two stock exchange centres were set up in Shanghai and Shenzhen. The advantages of incorporation were clearly comprehended by the Chinese business and industrial sectors. In 1993, the number of registered companies reached $836,000 .{ }^{92}$ Such vigorous corporate activity called for appropriate legal regulation. The earliest company regulations after the economic reforms were locally enacted, such as the Regulations for Foreign Related Companies in Special Economic Zones in Guangdong Province (1986) and the Shenzhen City, Interim Regulations on Companies Limited by Shares (1992). These

87 Generally see the discussions in the World Bank, China: Problems and Policies of Long-Term Development, The World Bank, Washington DC, 1983.

88 Generally see State Council, Some Regulations Concerning Deepening Enterprise Reform and Increasing Enterprise Vitality, 1996.

89 See Liu, Zhang and Meng, above n 12, p 18.

90 Ibid.

91 Ibid.

92 The total number of companies (including non-registered companies) was 1,104,000. See the State Statistical Bureau, PRC, Chinese Statistical Yearbook, China Tongji Publishing House, Beijing, 1993, p 93. 
local corporate statutes provided useful guidelines for the codification of a national company law. In 1993, after 10 years of preparation, the first company code of the People's Republic of China was finally completed and enacted.

The scheme to draft a national company law had been initiated in 1983 by the National Economic Committee. The original plan was to draft legislation for stock companies (public companies) and limited companies (private companies) separately. This was because of concerns that the experience of corporations in China was insufficient, and the management of public companies was far more complicated than that of limited companies. ${ }^{93}$ Hence, it would be convenient to draft separate laws for them, and whichever was completed first would be enacted earlier. ${ }^{94}$

The drafting work began in 1986. After two years' work, the draft Regulations on Limited Companies and Regulations on Companies Limited by Shares were submitted to the State Council for examination. The State Council amended the drafts in 1988 and 1989. In 1991, a draft Limited Company Law was completed and after some amendments, was finalised in 1992. The draft law had a very narrow field of operation. It only regulated the companies owned by two or more state-owned or collective-owned enterprises. ${ }^{95}$ When the draft law was sent to the Standing Committee of the People's Congress, it was the general opinion of the committee that the coverage of the law was too narrow, and it was necessary to make a company law with wider coverage in order to accommodate the economic development. ${ }^{96}$ Afterwards, the Legal Committee of the People's Congress and the Legal Committee of the State Council assumed the task of drafting a comprehensive company code. The drafters referred to China's early company legislation and drafts, studied foreign legislative experience, listened to experts' opinions, and eventually produced a draft company code. After much examination and many amendments, the first Company Law of the People's Republic of China was passed by the People's Congress on 29 December 1993. It came into effect in 1994. Minor amendments were made to the 1994 Company Law in 1999. Article 67 is amended to facilitate China's state-owned enterprise reforms by introducing supervisory boards into wholly state-owned companies, and Art 229 is amended to encourage high and new technology public companies to list on stock exchanges.

The Company Law specifically provides that companies must manage their business independently according to the needs of market, and that they are independently responsible for profits and losses. ${ }^{97}$ This is a total departure from the old notion that the function of enterprises is to implement State plans.

In contrast to previous legislation, the Company Law classifies enterprises according to investors' liability and capital structures rather than ownership. This is a demarcation indicating that China's enterprise system is developing

\footnotetext{
93 See Wang and Cui, above n 17, p 18.

94 Ibid.

95 Generally see Explanations on the Limited Company Law of the People's Republic of China (28 July 1992) which was made by the head of the Legal Bureau of the State Council, Yang Jingyu to the Standing Committee of the People's Congress.

96 See Wang and Cui, above n 17, p 20.

97 Company Law (1994), Art 5.
} 
towards a market economy. Consequently, the presumption that state-owned enterprises are superior to enterprises with other kinds of ownership has diminished.

China's corporate law has definitely inherited the legacy of foreign corporate laws, especially Anglo-American and German corporate laws. However, compared with current developments in other jurisdictions, the Chinese Company Law has some distinctive characteristics. Firstly, it emphasises the central role of the shareholders' meeting. This is quite a conservative, if not reactionary, approach. The shareholders' meeting has a wide range of powers, including the power to make business policies and plans, to decide on matters such as reconstruction and dissolution of the company, to increase or to reduce registered capital, and to issue shares. ${ }^{98}$ The board of directors is the executive organ of the shareholders' meeting and it is responsible to the shareholders' meeting. ${ }^{99}$ The legislative scheme was motivated by the concern that China had had a planned economy for too long, and thus lacked a tradition of investors participating in enterprises' decision-making processes. The Company law therefore needs to stress the power of the shareholders' meeting in order to ensure that the meeting will function effectively. ${ }^{100}$

Secondly, the Company Law emphasises the function of capital in a company. It requires companies to register a minimum amount of capital and stresses the importance of capital maintenance. ${ }^{101}$ The purpose of doing so is to protect shareholders' and creditors' rights and interests so as to enhance investor confidence. ${ }^{102}$

Thirdly, the Company Law is a single company code by which public companies and closely held companies are regulated, with separate provisions for each form of company in relevant areas. In the process of drafting the law, it was perceived to be unnecessary to introduce every possible type of company into China. As a result, the law provides for three types of companies: (1) state-owned companies; (2) stock companies (public companies); and (3) limited companies (private companies). The latter two are the basic types of companies in most corporate systems.

Fourthly, the Chinese Company Law adopts the German two-tier board system. It is believed that this system provides a governance structure that delivers a strong monitoring function over managerial performance. By clearly dividing powers among corporate organs, this structure is somewhat superior to a one-tier board structure. Theoretically, a separate supervisory board responsible for monitoring the executives and financial affairs of the company is a more effective arrangement to ensure that supervision is exercised independently and effectively. Under the law, supervisory boards are mandatory for stock companies. Limited companies may or may not have supervisory boards, depending on their size and their number of shareholders.

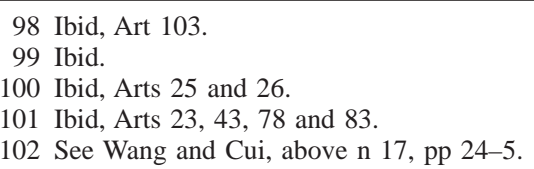


If a company is small in size and has a small number of shareholders, it only needs one or two supervisors. ${ }^{103}$

However, China's two-tier board system does not exactly follow the German system. In Germany, a supervisory board also has the power to supervise the company's financial affairs and to make business decisions as well as the power to supervise the board of directors and company operations. Its members are appointed by the shareholders' meeting. After the appointment, the supervisory board elects the members of the board of directors. The board of directors has a duty to submit their work reports to the supervisory board. Hence, in the German system, the supervisory board is not only a supervisory organ but also a decision-making organ of the corporation with authority over the board of directors. ${ }^{104}$

In China, the supervisory board does not have much power over the board of directors of a company. The supervisory board does not make business decisions and it has no say in the appointment of directors. According to the 1994 Company Law, the shareholders' meeting has the authority to elect the directors and the supervisors of a company. Both boards are obliged to submit their reports to the shareholders' meeting for review and approval. Article 54 of the Company Law states that the major function of the supervisory board includes examining the company's financial affairs, supervising directors' and managers and proposing interim shareholders' meetings. Thus, in a Chinese company, the supervisory board is merely an organ responsible for supervising the board of directors and corporate operations, rather than a decision-making organ. Supervisors must be elected from a company's shareholders and employees. However, for obvious reasons, directors and managers and those in charge of the company's financial affairs are not able to serve on the supervisory board. ${ }^{105}$

It is also noteworthy that the Company Law takes a conservative position in many respects. For example, it retains the ultra vires doctrine and par value, ${ }^{106}$ and forbids one man companies. ${ }^{107}$ These appear to be old fashioned approaches in comparison to the current legislative trends in other jurisdictions such as the United States, the United Kingdom, Canada, New Zealand, and Australia. ${ }^{108}$ The conservative approach may have been perceived necessary because China is in an early stage of corporate development.

It is of further note that the Company Law leaves many gaps. For example, it does not clarify the nature of directors' duties. In Anglo-American systems, directors are fiduciaries and owe fiduciary duties to their companies and shareholders. In civilian systems, directors are regarded as trustees of their

103 Articles 38, 52 and 124 of the 1994 Company Law.

104 See Y Xu, The Principles of Company Law, Law Publishing House, Beijing, 1997, p 238. 105 Ibid, pp 294-5.

106 Company Law (1994), Arts 11, 22 and 131.

107 Only the State can set up a State owned company with one shareholder.

108 Following the US model of corporate legislation, Canada, New Zealand and Australia all carried out drastic corporate reforms. In these reforms the ultra vires doctrine and the concept of par value were abolished, and one-man companies were permitted. The CBCA even eliminates the traditional distinction between a private company and a public company. 
companies. ${ }^{109}$ While the 1994 Company Law remains silent on the issue, Chinese academics believe that the reality in China suggests that directors should be seen as the agents of their companies. ${ }^{110}$ There are no provisions concerning shareholders' class action and derivative suits. The law even fails to address the quorum for a shareholders' meeting. It is unknown whether the gaps will be filled by further amendments or by enacting detailed regulations that implement the Company Law.

Nevertheless, the significant impact of the Company Law on China's enterprise system and economic reforms was unprecedented. It indicates a complete change of the enterprise system in modern China. Modern companies have become the dominant business form and play the major role in productive activities. The Company Law provides legal guidance and protection for corporate practices.

For those companies that existed before its enactment, the Company Law allowed them to be registered as companies within a certain period, if they met the requirements of the law. In 1995, the State Council issued the Announcement for Regulating Previous Stock Companies and Limited Companies in accordance with the Company Law of the People's Republic of China, which contained detailed provisions relating to the re-registration of companies previously existing before the enactment of the Company Law. Such companies could have been registered before 31 December 1996, if they met the requirements of the law. Those companies which failed or refused to register under the requirements of the Company Law before that date are no longer permitted to operate as companies or to have the word 'company' in their names.

The Company Law has provided a clear legal guide for corporate practice. After the enactment of the law, the trial of reforming existing state-owned enterprises into corporations began. About 2500 large and medium sized enterprises joined in the trial.111 Up until 1997, one third of them had completely reformed. Among them, 540 enterprises were transformed into stock companies, 540 into limited companies, and 909 into state-owned companies. ${ }^{112}$ Public ownership in these companies exists in the form of shareholdings.

When the corporate form became predominant, people gained a keener understanding of corporate logic. The Chinese have been increasingly aware that a mere adoption of the corporate form does not substantially improve enterprise behaviour or economic efficiency. Some newly converted companies still operate in the old manner. ${ }^{113}$ Hence, to plant a modern enterprise system in China requires more effort than simply enacting a company law. It requires a range of institutional reforms. Chinese reformers

109 The term of trustee in civilian systems has a meaning different from the definition in common law systems. In here a trustee is not a fiduciary.

110 See H Chen and J W Liu (Eds), Research on the State Owned Enterprise Reform and Corporate Law, Publishing House of Xiamen University, China, 1997, pp 92-106.

111 See Chen, above n 68, p 149.

112 Ibid.

113 See C Y Zhang, 'Analysis on Misunderstanding the Corporatisation', Jing Ji Ri Bao, 28 April 1992, p 2. 
have thus turned their attention to devising corporate governance mechanisms that enhance corporate accountability.

\section{(ii) The enterprise reform in the context of the economic reforms (1978-1997)}

Since the commencement of the economic reforms in 1978, China's economy has realised an average annual growth rate of $9 \%$. The agricultural sector and non-State enterprises have been largely responsible for this success. However, the financial performance of state-owned enterprises has declined. In 1996, about half of the state-owned enterprises of the industrial sector made net losses that amounted to $1.3 \%$ of China's gross domestic product (GDP). ${ }^{114}$ The unsatisfactory performance by Chinese state-owned enterprises has largely resulted from the lack of a modern, market-oriented enterprise system. This raises the fundamental question: why did the Chinese Government fail to launch a far-reaching enterprise reform policy in the early stages of the economic reforms?

There were both ideological and economic reasons for the postponement of fundamental reform of the enterprise system. Ideologically, in China, it was a popular view that public ownership was superior to private ownership. It was believed that a fundamental reform had to involve a certain degree of corporatisation and privatisation of state-owned enterprises. This would in turn erode public ownership. People with this view believed that public ownership was superior to private ownership, and that it was crucial to maintain social stability in the course of economic reforms. If the dominance of public ownership was eroded by economic reforms, polarisation would be inevitable. This would exacerbate all conflicts, including those between different areas, different levels of governments, and different ethnic groups, and bring a disastrous outcome. ${ }^{115}$

The principal economic justification for delaying the enterprise reform was the concern about the social cost of such reform at a macro-economic level. When the economic reforms commenced, state-owned enterprises accounted for $60.3 \%$ of China's GDP and collectively-owned enterprises accounted for $34.6 \%$. In the manufacturing sector, four-fifths of the output was produced by state-owned enterprises. ${ }^{116}$ State-owned enterprises employed over two-thirds of all industrial employees and owned a majority of total fixed assets. ${ }^{117}$ They also provided social welfare to employees, retirees and their families. The initial size and the dominant role of state-owned enterprises in the economy determined that it was not desirable to reform the enterprise system drastically. It was perceived that a radical enterprise reform would produce massive urban unemployment and create social division between the rich and the poor, which would in turn bring social instability and jeopardise the entire

114 See the World Bank, China's Management of Enterprise Assets: The State as Shareholder, the World Bank, Washington DC, 1997, p xi.

115 See M W Chen's remarks in W M Zhang et al (Eds), The Great Economic Debate in China, Publishing House of Economic Management, Beijing, 1997, pp 69-70.

116 See Lardy, above n 79, p 25.

117 State Statistical Bureau (China), Statistical Yearbook of China, 1986, Oxford University Press, London, 1986, pp 95, 97, 189 and 224. See also Lardy, above n 79, p 25. 
reform program. Taking account of such potential high social costs, the Chinese regarded it worthwhile to adopt less radical methods to reform the enterprise system. ${ }^{118}$ As a result, the enterprise reform in China has been carried out in phases.

The first phase of the enterprise reform started in 1978. It focused on decentralising governmental authority in enterprises and on increasing the operational autonomy of enterprise managers. ${ }^{119}$ Methods such as the contract responsibility system, ${ }^{120}$ leasing and 'corporatisation' were used. Managers were given greater autonomy over the allocation of profits and resources. ${ }^{121}$ The government also encouraged the development of enterprises with diversified ownership, including Chinese foreign joint ventures, and privately owned and individually owned enterprises.

With the increasing expectation of improvement in enterprise efficiency, the second phase of enterprise reform was began in the mid-1980s. ${ }^{122}$ During this period, the government, while continually encouraging managerial autonomy, promoted the formation of long-term contracts between enterprises and their administrative departments. By explicating financial targets for the enterprises in such contracts, it was expected that opportunities for bureaucratic intervention would be reduced, and the managerial performance and economic efficiency of the enterprises improved.

In 1993, the third phase of enterprise reform began. The introducing of modern corporate governance mechanisms into state-owned enterprises was emphasised, and trials of corporatisation and privatisation were carried out in selected sectors and enterprises.

After years of reform efforts, the progress of Chinese enterprises was impressive. Up until the late 1990s, the growth rate of total factory productivity steadily increased. ${ }^{123}$ The economic efficiency of state-owned enterprises appeared to improve, although not as significantly as that of non-State owned enterprises. ${ }^{124}$ state-owned enterprises remained the key protagonists of the nation's industrial sector and dominated most capital-intensive sectors. ${ }^{125}$ However, the performance of state-owned enterprises was by no means satisfactory. Their profits declined from $6 \%$ of the GDP in the 1980s to $1 \%$ of the GDP in the late 1990s. ${ }^{126}$

State-owned enterprises suffered from several major problems: Firstly, the enterprises were excessively burdened by a range of social obligations. ${ }^{127}$ Under the planned economy, China did not develop a social security and

118 See Lardy, above n 79, pp 22-3.

119 Ibid.

120 The system was designed to urge directors of enterprises to improve the enterprises' productivity and profitability. Directors and supervisory administrative departments signed performance contracts and the directors' work records were connected with the performance of their enterprises.

121 See Lardy, above n 79, pp 22-3.

122 Ibid, p 23.

123 See the World Bank, above n 114, p 1

124 See T Grove, Y Hong, J McMillan and B Naughton, 'Autonomy and Incentives in Chinese State Enterprises' (1994) 109 (1) Quarterly Jnl of Economics 183-8.

125 See the World Bank, above n 114, p 1.

126 Ibid.

127 Ibid. 
welfare system. Instead, the enterprises were liable for providing such social services to employees, retirees and their families. Since the beginning of the economic reforms, the State had made efforts to relieve the enterprises from such encumbrances by developing a social security and welfare system. However, before such a system was fully completed and functional, many enterprises had to continue to assume social responsibilities. As a result, state-owned enterprises operated with a large number of redundant employees and retirees. This disadvantaged them competitively. As a result, many state-owned enterprises made net losses. Moreover, because they accepted social responsibilities for the State, they were not able to exit freely. For certain policy reasons, the government had little choice but to inject capital into loss-making or insolvent enterprises continually. This revealed a second major problem of China's enterprise system: China's banking system did not operate commercially.

The banks in China were not intermediaries between savers and investors as their counterparts were in market economies. ${ }^{128}$ They did not assume a disciplinary role as banks did in market economies either. ${ }^{129}$ Under China's planned economy, a mono-bank system existed where each bank operated as a central bank and a commercial bank. Banks operated according to administrative plans rather than commercial principles. This situation did not improve fundamentally after the economic reforms. The government continued to control interest rates and to impose credit plans on banks. Consequently, banks extended a large proportion of 'policy loans' to state-owned enterprises and had to underwrite loss-making enterprises constantly. ${ }^{130}$ Sometimes, bank loans were used by enterprises to pay their workers' wages and bonuses rather than make profits. The non-commercial operation of the banking system created a fatal problem for the enterprise system, ie, inefficient allocation of capital. If the problem persists, China's major banks could all be dragged into insolvency. ${ }^{131}$

Price distortion was another problem that plagued state-owned enterprises. For policy reasons, the State continually exercised the power to set prices for state-owned enterprises. This further disadvantaged state-owned enterprises in market competition. The situation was more serious in the early stage of the reforms. With the expansion of the price reform, the problem was mitigated. However, the government has retained some measures of control over certain products in particular sectors, such as price ceilings. ${ }^{132}$

Finally, the early strategies of enterprise reform created new problems in the enterprise system. While the managers of state-owned enterprises were increasingly given managerial autonomy, the property rights in the enterprises were not clearly defined. This created an opportunity for the management of state-owned enterprises to transfer enterprise assets to non-state-owned enterprises. Managerial autonomy also created an insider control problem, which led to excessive wage payment in some enterprises. Tax evasion and

128 See Lardy, above n 79, pp 59-61.

129 Ibid.

130 Ibid, $\mathrm{p} 83$.

131 It is suspected that the major banks are already insolvent.

132 See Broadman, above n 78, p xv. 
de-capitalisation also became severe. ${ }^{133}$ These problems further contributed to the decline in profitability of state-owned enterprises.

In summary, the policy of enterprise reform in China has not been made in isolation. It has been formulated in the context of broad economic reform considerations. The fear of instability inspired the Chinese government to adopt an economic reform strategy designed to prevent the emergence of economic losers during the reform era. This in turn deferred the acceptance of a radical reform of state-owned enterprises, and the Chinese economy has constantly paid the price for the delay. The situation later deteriorated to the point that, without radical enterprise reform or effective measures being adopted, the gains from the successful economic reforms could all be consumed by the inefficient enterprise system.

\section{(iii) The initiation of the 'big bang' enterprise reform since 1997}

Seeing the alarming problems in the enterprise system, the Chinese Government finally determined to initiate the 'big bang' enterprise reform package in 1997. The Fifteenth National Congress of the Communist Party of China (the congress) sketched out the blueprint for the enterprise reform. The congress confirmed that the next stage of the economic reforms should focus on reforming large and medium-sized state-owned enterprises into modern corporations in order to set up a modern enterprise system in China. Corporatisation and privatisation of state-owned enterprises were to be carried out on an ever large scale.

In September 1999, the Fourth Plenum of the Fifteenth Communist Party of China (CPC) Central Committee further defined the major objectives and guiding principles for the reform and development of state-owned enterprises. According to the Decision of the CPC Central Committee on Major Issues Concerning the Reform and Development of State-Owned Enterprises, the objectives for the state-owned enterprise reform and development up until the year 2010 are: to complete strategic readjustment and restructuring; to bring into form a more rational layout and structure of the national economy; to establish a relatively perfect modern corporate system; to improve economic performance; to promote scientific and technological development, market competition and risk management; and to make the State economy play a better, dominant role in the national economy. ${ }^{134}$ The guidelines for the reform and development of state-owned enterprises include: the maintenance of public ownership as the dominant form; the strategic readjustment of the State economy and the restructuring of state-owned enterprises; the establishment of a modern corporate system; and the fostering of a competitive mechanism based on survival of the fittest. ${ }^{135}$

Under the current policy, public ownership of enterprises can be reduced to

133 See H G Broadman, 'China's membership in the WTO and Enterprise Reform: The Challenges for Accession and Beyond', SSRN Journal, 30 May 2000, $\langle$ http://papers.ssrn.com/paper.taf?abstract_id=223010 .

134 Generally see the Decision of the CPC Central Committee on Major Issues Concerning the Reform and Development of State-owned Enterprises, 22 September 1999.

135 Ibid. 
a non-dominant proportion, except some important sectors. ${ }^{136}$ State-owned enterprises will only remain dominant in the following industrial sectors: (1) pillar industries and backbone enterprises in high technology sectors; (2) non-renewable natural resource sectors; (3) public utility and infrastructure service sectors; (4) sectors vital to the country's national security. ${ }^{137}$ This shows the government's determination to introduce a diversified ownership structure into the enterprise system so as to encourage competition for state-owned enterprises.

In 1998, the government took radical steps to shift its role from directly controlling enterprises by providing them with indirect and strategic planning. ${ }^{138}$ The government ministries were restructured to suit the market economy better and more than 200 of their functions were delegated to enterprises. ${ }^{139}$ Enterprises are now obliged to lodge financial statements with financial intermediaries. All of the efforts illustrate the government's determination to subject state-owned enterprises to greater financial controls. ${ }^{140}$

Mechanisms were also introduced to enhance industrial rationalisation. An increasing number of loss-making enterprises were restructured through bankruptcy, mergers and acquisitions. In 1997, about 650 enterprises declared bankruptcy and over 1000 enterprises were acquired. ${ }^{141}$ The numbers doubled in 1998. Recently, the bankruptcy and acquisition scheme began to target large and medium-size enterprises.

The banking system has been subject to restructuring. The banking sector reform has focused on reducing the rate of non-performing loans in the system, in order to limit financial risks and to prevent future financial crises. ${ }^{142}$ In 1998, the Ministry of Finance strengthened the major banks' capital bases by issuing them with additional treasury bonds. A new indicative quota system and an asset and liability management system were introduced in the same year. It is expected that the new systems will be helpful to reduce non-performing loans. ${ }^{143}$

To ensure the success of the reform, the Chinese Government has put the development of a sound social security system high on the agenda. From July to December 1999, the government raised the minimum level of unemployment insurance and the lowest income of urbanites by $30 \% .{ }^{144}$ A framework for a social security system consisting of pensions, unemployment and medical insurance was set up by the end of 2000 .

136 The policy was clarified by the Fourth Plenum of the Fifteenth Party Central Committee in a Decision in 1999 and by the State Development Planning Commission in a statement in 2000. See Broadman, above n 133.

137 Ibid.

138 See the World Bank, China, Weathering the Storm and Learning the Lessons, The World Bank, Washington DC, 1999, p 32.

139 Ibid.

140 Ibid.

141 Ibid, p 30.

142 Ibid, p 33.

143 Ibid, pp 33-4.

144 The Editor, 'SOEs Improve Economic Efficiency', People's Daily Online, 31 December 1999, <http://english.peopledaily.com.cn/home.html>. 


\section{Conclusion}

The evolution of China's corporate system happens in the context of its economic reforms, which began in the late 1970s and is currently in full swing. This grants greatest significance to discussions on this topic.

As early as the late nineteenth century, some Chinese intellectuals began to introduce corporate concepts into Chinese society. They enthusiastically praised the function of companies and promoted to adopt a corporate system in China. They attributed the rise of western economies to corporate practice, and believed that the corporate system could enhance a nation's strength and increase the wealth of a society. They saw the corporate system as the all-powerful method of developing a nation and considered that corporatisation was the only way that could lead China's move to modernisation. However, the defective corporate practice illustrates the fact that legal acceptance does not amount to social acceptance.

China's social and economic conditions at the beginning of the reforms justified a gradual reform strategy. The reform cost was kept as low as possible at a macro-economic level. However, it was achieved at the expense of micro-economic efficiency. As the economic inefficiency at a micro-economic level has accumulated to an extent that it is jeopardising the entire outcome of the economic reforms, it is time to devote full attention to corporate governance. As a result, the government finally clarifies that state-owned enterprises should be reformed into corporations. The final decision as to corporatisation is based on years of reform experiment and deliberation.

In the course of corporatisation, the Chinese have to learn more than transplantation of a set of laws. With an increasing comprehension of how the modern corporation operates and succeeds, the Chinese gain more confidence in their enterprise reform. It is almost certain that the current enterprise reform will not only change the performance of Chinese companies but will also change Chinese society in many ways. The corporatisation thus is a far more significant event than a micro-economic revolution. 